\title{
Concanavalin A Inhibits Tissue Factor Coagulant Activity
}

\author{
Frances Ann Pituick \\ From the Department of Internal Medicine, Yale University School of Medicine, \\ New Haven, Connecticut 06510
}

\begin{abstract}
A B S T R A C T Concanavalin A (con A) is a potent inhibitor of coagulant activity of native tissue factor. Coagulant activity is recovered by addition of $\alpha$-methyl- $D$ glucoside to inhibited tissue factor. Inclusion of $\alpha$-methylD-glucose during incubation of con $\mathrm{A}$ with tissue factor preserves coagulant activity. These data suggest that con A interacts reversibly with a carbohydrate residue in such a way as to inhibit coagulant activity of the molecule.

Purified tissue factor apoprotein has been recombined with mixed brain phospholipids or purified phospholipids (phosphatidyl ethanolamine or a mixture of phosphatidyl choline with phosphatidyl serine). These preparations were also completely but reversibly inhibited by con A. Thus, purified tissue factor apoprotein appears to donate the affected carbohydrate residue.
\end{abstract}

\section{INTRODUCTION}

Rapid initiation of coagulation occurs when tissue factor, a membrane-bound lipoprotein, is added to normal plasma. Accumulating evidence suggests that tissue factor is a glycoprotein derived from plasma membrane: (a) purified tissue factor contains carbohydrate (1); (b) tissue factor antigen is found on the cell surface $(2,3)$; (c) tissue factor activity has been localized histochemically to the plasma membrane $(4) ;(d)$ tissue factor activity can be stripped from cells in culture without loss of intracellular material (5). We now report another observation consistent with previous data: concanavalin A (con A) ${ }^{1}$ inhibits the coagulant activity of purified tissue factor.

Con $\mathrm{A}$ is a plant lectin which binds preferentially to mannosyl or glucosyl residues whose reducing termini are blocked (6). Con A does bind certain glycoproteins (for example, rhodopsin (7), probably through inter-

Received for publication 29 January 1974 and in revised form 5 August 1974.

${ }_{1}^{1}$ Abbreviations used in this paper: con A, concanavalin A; DIP, diisopropylphosphoryl; DFP, diisopropylphosphorofluoridate; IBS, $0.05 \mathrm{M}$ imidazole- $0.1 \mathrm{M} \mathrm{NaCl}, \mathrm{pH}$ 7.2; MBL, mixed brain lipids; $P C$, phosphatidyl choline; $P E$, phosphatidyl ethanolamine; PS, phosphatidyl serine. action with the mannosyl or glucosyl residue in polysaccharide chains along the peptide backbone.

Con A inhibition of tissue factor activity of cultured fibroblasts has recently been reported (8); data presented here show that tissue factor protein retains sensitivity to con A after purification, suggesting that tissue factor itself is a glycoprotein.

\section{METHODS}

The purified bovine phospholipids phosphatidyl ethanolamine $(\mathrm{PE})$, phosphatidyl choline (PC), and phosphatidyl serine (PS) were purchased from Supeclo, Inc., Bellefonte, $\mathrm{Pa}$. $\alpha$-Methyl-D-glucoside was purchased from Sigma Chemical Co., St. Louis, Mo. Sephadex G-50, medium, and DEAESephadex are products of Pharmacia Fine Chemicals Inc., Piscataway, N. J.

Protein concentrations were determined by the technique of Lowry, Rosebrough, Farr, and Randall (9). Phospholipid was estimated from phosphorous content determined by the method of Chen, Toribara, and Warner (10).

Con A was purified by the method of Agrawal and Goldstein (11). This material was then readsorbed onto Sephadex ( $0.4 \mathrm{~g}$ Sephadex per $\mathrm{mg}$ protein) and poured into a column which was washed with $1 \mathrm{M} \mathrm{NaCl}$. Con A was eluted from the column with $0.1 \mathrm{M}$ sucrose in $1 \mathrm{M} \mathrm{NaCl}$.

A preparation of EDTA-washed acetone powder from bovine brain (12) was used as a source of crude tissue factor. Tissue factor apoprotein was purified from bovine brain according to the method of Nemerson and Pitlick (1), modified as described in Rickles, Hardin, Pitlick, Hoyer, and Conrad (13). Mixed brain lipids (MBL) were prepared by method 1 of Nemerson (14). Apoprotein was relipidated according to the general procedure described by Nemerson (15) with a final protein concentration of $25 \mu \mathrm{g} / \mathrm{ml}$ after relipidation. The lipid to protein ratios (micrograms per microgram) and specific activities (units per milligram) were as follows: MBL, 5:1, 17,600; $\mathrm{PE}, 5: 1,30,080$; PS : PC, $5: 5: 1,20,000$.

For convenience, the tissue factor assay was modified slightly from that previously reported (14); partially purified reagents have been substituted for the barium citrate elutate; bovine plasma depleted of factor VII and activated contact factors was used as substrate plasma (16), and finally, the end points were measured on a Coag-a-Mate machine (Alphamedics Mfg. Corp., Levittown, Pa.). The clotting times and slope of the standard curve were comparable with the previous assay.

Factor VII was partially purified by DEAE-Sephadex chromatography of a serum eluate from barium sulfate

The Journal of Clinical Investigation Volume 55 January 1975-175-179 
TABLE I

Con A Inhibition of Crude Tissue Factor

\begin{tabular}{|c|c|c|c|c|c|c|c|}
\hline \multirow[b]{2}{*}{ Con A } & \multicolumn{2}{|c|}{ Con A alone } & \multicolumn{2}{|c|}{ Reversal by $\alpha$ MG* } & \multicolumn{2}{|c|}{ Protection by $\alpha \mathrm{MG}$} & \multirow{2}{*}{$\begin{array}{c}\begin{array}{c}\text { Buffer } \\
\text { control }\end{array} \\
\text { Units }\end{array}$} \\
\hline & Units & Inhibition & Units & Recovery & Units & $\%$ Control & \\
\hline$\mu g / m l$ & & $\%$ & & $\%$ & & $\%$ & \\
\hline 0.1 & 135 & 31 & 150 & 77 & 170 & 87 & 195 \\
\hline 10.0 & 29 & 86 & 160 & 78 & 155 & 76 & 205 \\
\hline 50.0 & 17 & 91 & 165 & 85 & 150 & 77 & 195 \\
\hline
\end{tabular}

EDTA brain $(300 \mathrm{U} / \mathrm{ml}, 1.5 \mathrm{mg} / \mathrm{ml})$ was incubated at $37^{\circ} \mathrm{C}$ for $50 \mathrm{~min}$ with buffer alone (no con A or $\alpha \mathrm{MG}^{*}$ ), con $\mathrm{A}$ alone, con $\mathrm{A}$ alone for $25 \mathrm{~min}$ before the addition of $\alpha \mathrm{MG}$ (reversal), or $\alpha \mathrm{MG}$ and con A together for $50 \mathrm{~min}$ (protection). All samples were then assayed directly for tissue factor activity.

${ }^{*} \alpha \mathrm{MG}, \alpha$-methyl-D-glucoside.

using a salt gradient of $0.05 \mathrm{M}$ Tris- $0.12 \mathrm{M} \mathrm{NaCl}$ to $0.05 \mathrm{M}$ Tris-0.6 M NaCl, $\mathrm{pH}$ 7.5. Factor $\mathrm{X}$ was purified in a similar manner from bovine plasma. The factor VII specific activity was $608 \mathrm{U} / \mathrm{mg}$; factor $\mathrm{X}$ specific activity was 4,480 $\mathrm{U} / \mathrm{mg}$ ( $1 \mathrm{ml}$ plasma contains $100 \mathrm{U}$ of each factor). The two preparations were stored separately in $50 \%$ glycerol at $-20^{\circ} \mathrm{C}$ and aliquots were used as needed. Before assay, the two factors were mixed in the ratio of $38 \mathrm{U}(84 \mu \mathrm{g})$ factor VII per $\mathrm{ml}$ and $4.5 \mathrm{U}(1 \mu \mathrm{g})$ factor $\mathrm{X}$ per $\mathrm{ml}$. Equal volumes $(20 \mu 1)$ of the factor VII : X mixture, tissue factor, and $0.025 \mathrm{M} \mathrm{CaCl}_{2}$ were incubated exactly $1 \mathrm{~min}$ at $37^{\circ} \mathrm{C}$ before the simultaneous addition of $50 \mu \mathrm{l}$ of each factor VIIdepleted plasma and $0.025 \mathrm{M} \mathrm{CaCl}$. With these amounts of factors VII and X, the assay was insensitive to added amounts of either factor but dependent upon the amount of tissue factor added. Tissue factor activity is reported in terms of the EDTA brain standard used in this laboratory (14) ; $100 \mathrm{U}$ EDTA brain standard contains $0.5 \mathrm{mg}$ protein and $0.5 \mathrm{mg}$ phospholipid.

To study the inhibition of tissue factor activity by con A, a series of tubes was set up for incubation at $37^{\circ} \mathrm{C}$. In one tube, $0.1 \mathrm{ml}$ of an appropriate dilution of the tissue factor sample was further diluted with $0.3 \mathrm{ml}$ of $0.05 \mathrm{M}$ imidazole-0.1 $\mathrm{M} \mathrm{NaCl}, \mathrm{pH} 7.2$ (IBS); this sample is designated "buffer control." In another tube, $0.2 \mathrm{ml} \alpha$-methyl-D-glucoside $(200 \mathrm{mg} / \mathrm{ml})$ was added to $0.1 \mathrm{ml}$ tissue factor and $0.1 \mathrm{ml}$ con $\mathrm{A}$ was then added. This sample is referred to as "protected." These two sets of controls were incubated for $50 \mathrm{~min}$. To $0.1 \mathrm{ml}$ tissue factor in the third and fourth tubes was added $0.1 \mathrm{ml}$ con A. After $25 \mathrm{~min}$ incubation, $0.2 \mathrm{ml}$ IBS ("inhibition") or $\alpha$-methyl-D-glucoside ("reversal") was added, and the incubation continued for another $25 \mathrm{~min}$. All samples were then placed in melting ice and assayed directly without further dilution. The samples were gently mixed before assay so that any particulate material was resuspended.

\section{RESULTS}

Inhibition of crude tissue factor by con $A$. The results presented in Table $I$ show that increasing concentrations of con $A$ result in greater inhibition of tissue factor coagulant activity, and that at $50 \mu \mathrm{g} / \mathrm{ml}$, activity is $91 \%$ inhibited. If $\alpha$-methyl-D-glucoside is added to inhibited tissue factor, the activity approaches full recovery compared to the sample which contained
$\alpha$-methyl-D-glucoside at the beginning of the incubation with con A.

Effect of con $A$ on factors $V I I$ and $X$. To demonstrate the con A was reacting specifically with tissue factor rather than with factors VII or $\mathrm{X}$ in the activity assay, the factor VII: $\mathrm{X}$ reagent was preincubated with con $\mathrm{A}$ at $10 \mu \mathrm{g} / \mathrm{ml}$ for $1 \mathrm{~min}$ (the time of exposure during assay) before the addition of calcium and tissue factor. No difference in clotting time (26 s) was observed when compared with a buffer control.

Sensitivity of purified tissue factor to con $A$. Crude tissue thromboplastin contains a variety of proteins and lipids, including gangliosides; activity, however, is dependent upon the protein moiety $(12,13,15)$. Thus, it was necessary to determine that the effect of con A on tissue factor activity was a result of binding to glycoprotein and not to glycolipid. Accordingly, we relipidated the apoprotein with a crude preparation of MBL or with purified phospholipids. Relipidation with $\mathrm{PE}$ results in a more active lipoprotein than when MBL are used. PS: PC relipidation produces a lipoprotein with activity equivalent to the sample relipidated with MBL, although greater amounts of lipid are required. The activity of this preparation is greater than the activity generated using the same amounts of the individual lipid components (Pitlick, unpublished data).

Equivalent amounts of tissue factor activity (about $100 \mathrm{U} / \mathrm{ml}$ ) were incubated with con A (Table II). Because the sample relipidated with $\mathrm{PE}$ had higher specific activity than the samples relipidated with MBL or PS: $\mathrm{PC}$, it was used at a lower protein concentration. In these experiments, $\alpha$-methyl-D-glucoside and con A together appeared to stabilize activity during incubation as compared with buffer alone (column 6 vs. column 8).

With all three lipoproteins, total inhibition of activity is observed at a con A concentration of $10 \mu \mathrm{g} / \mathrm{ml}$; with 
TABLE II

Con A Inhibition of Purified Tissue Factor

\begin{tabular}{|c|c|c|c|c|c|c|c|}
\hline \multirow[b]{2}{*}{ Con $\mathbf{A}$} & \multicolumn{2}{|c|}{ Con $\mathrm{A}$ alone } & \multicolumn{2}{|c|}{ Reversal by $\alpha \mathrm{MG}^{*}$} & \multicolumn{2}{|c|}{ Protection by $\alpha$ MG } & \multirow{2}{*}{$\frac{\begin{array}{c}\text { Buffer } \\
\text { control }\end{array}}{\text { Units }}$} \\
\hline & Units & Inhibition & Units & Recovery & $\%$ Units & Control & \\
\hline$\mu g / m l$ & & $\%$ & & $\%$ & & $\%$ & \\
\hline \multicolumn{8}{|l|}{ MBL } \\
\hline 0.1 & 60 & 0 & 58 & 97 & 70 & 117 & 60 \\
\hline 1.0 & 28 & 69 & 74 & 82 & 96 & 107 & 90 \\
\hline 10.0 & 0 & 100 & 44 & 73 & 86 & 143 & 60 \\
\hline \multicolumn{8}{|l|}{ PS/PC } \\
\hline 0.1 & 50 & 7 & 49 & 91 & 70 & 130 & 54 \\
\hline 1.0 & 14.5 & 80 & 35 & 49 & 66 & 92 & 72 \\
\hline 10.0 & 0 & 100 & 44 & 81 & 86 & 159 & 54 \\
\hline \multicolumn{8}{|l|}{$\mathrm{PE}$} \\
\hline 0.1 & 37 & 26 & 45 & 90 & 66 & 132 & 50 \\
\hline 1.0 & 17.5 & 70 & 44 & 76 & 60 & 103 & 58 \\
\hline 10.0 & 0 & 100 & 33 & 66 & 82 & 164 & 50 \\
\hline
\end{tabular}

Purified tissue factor was relipidated with several types of phospholipid. The lipid to protein ratio, protein concentration, and activity at the dilution incubated were as follows: $\mathrm{MBL}, 5 \mathrm{mg} / \mathrm{mg}, 780 \mathrm{ng}$ $(110 \mathrm{U}) / \mathrm{ml}) ; \mathrm{PS} / \mathrm{PC}, 5 \mathrm{mg}: 5 \mathrm{mg} / \mathrm{mg}, 780 \mathrm{ng}(125 \mathrm{U} / \mathrm{ml}) ; \mathrm{PE}, 5 \mathrm{mg} / \mathrm{mg}, 390 \mathrm{ng}(94 \mathrm{U} / \mathrm{ml})$. All incubations were at $37^{\circ} \mathrm{C}$ for $50 \mathrm{~min}$. Tissue factor was incubated with buffer alone (no con $\mathrm{A}$ or $\alpha \mathrm{MG}^{*}$ ), con A alone, con A alone for $25 \mathrm{~min}$ before the addition of $\alpha \mathrm{MG}$ (reversal), or $\alpha \mathrm{MG}$ and con A together for $50 \mathrm{~min}$ (protection). All samples were then assayed directly for tissue factor activity.

${ }^{*} \alpha \mathrm{MG}, \alpha$-methyl-D-glucoside.

con $\mathrm{A}$ at $1 \mu \mathrm{g} / \mathrm{ml}$, nearly an equivalent weight, about $70 \%$ inhibition is observed. At the lowest concentration tested, $0.1 \mu \mathrm{g} / \mathrm{ml}$ con $\mathrm{A}$, the PE lipoprotein appears to be more sensitive to inhibition, losing $26 \%$ of its activity.

When $\alpha$-methyl-D-glucoside is added to the inhibited samples activity returns. In the samples containing con A at $10 \mu \mathrm{g} / \mathrm{ml}$, the activity after reversal is at least $40 \%$ of the activity of samples containing $\alpha$-methyl-D-glucoside at the time of addition of con A. Similar results are obtained when the con A concentration is increased to $50 \mu \mathrm{g} / \mathrm{ml}$ and the $\alpha$-methyl-D-glucoside concentration is reduced to $25 \mathrm{mg} / \mathrm{ml}$, indicating that a maximum effect is achieved with the experimental conditions used in this study.

If the con A inhibition effect was due only to the binding of glycolipids, the lipoprotein containing MBL would be inhibited by con A, while the other two preparations would retain tissue factor activity. Such is not the case, however, since all three samples are relatively equally susceptible.

Time-course of inhibition. Activity begins to decrease immediately upon the addition of con $A$, the reaction approaching completion at $2.5 \mathrm{~min}$ (Table III). Incubations were continued for a longer period of time in the experiments to assure complete inhibition.

\section{DISCUSSION}

Tissue factor lipoprotein specifically interacts with factor VII which then becomes capable of activating factor $\mathrm{X}$, thus initiating coagulation. While the complete complex appears to be necessary for coagulant activity $(12,17)$, the factor $\mathrm{X}$ converting site appears to reside in the factor VII molecule $(18,19)$. In the bovine system, diisopropylphosphorofluoridate (DFP), the seryl protease inhibitor, blocks the coagulant activity of the complex and is incorporated into the factor VII

TABLE III

Time-Course of Con A Inhibition

\begin{tabular}{lr}
\hline Time & Units \\
\hline $\min$ & \\
0 & 110 \\
0.5 & 105 \\
1.0 & 72 \\
2.5 & 34 \\
4.0 & 31 \\
5.5 & 22
\end{tabular}

Relipidated tissue factor (5 ng PE/mg TF, $390 \mathrm{ng} \mathrm{TF} / \mathrm{ml}$ ) was incubated with con $\mathrm{A}(10 \mu \mathrm{g} / \mathrm{ml})$ at $37^{\circ} \mathrm{C}$ and assayed for coagulant activity at the times indicated. 
molecule $(12,18,19)$; there is no evidence that tissue factor hydrolyzes factor VII during complex formation (19). In native bovine plasma, factor VII incorporates DFP (diisopropylphosphoryl [DIP]-factor VII). Although biological activity is inhibited, DIP-factor VII still forms a complete (inactive) complex with tissue factor (19). This observation excludes the possibility that complex formation is mediated by proteolytic attack of factor VII on tissue factor. The data of $\varnothing$ sterud, Berre, Otnaess, Bjørklid, and Prydz (17) suggest that the activation of factor VII is reversible and that the complete tissue factor lipoprotein is necessary for full recovery of coagulant activity. Thus, although the molecular determinants of the tissue factor-factor VII interaction have yet to be defined, it appears that tissue factor lipoprotein presents a very specific surface for binding of factor VII, resulting in its ability to activate factor X.

Earlier, we noted that tissue factor protein contained carbohydrate (1). The purpose of the current experiments was to ascertain whether con $\mathrm{A}$ interaction with tissue factor would inhibit coagulant activity. Accomplishment of this objective required studying purified tissue factor, to exclude possible glycoprotein contaminants, and to relipidate with purified phospholipids in order to exclude the possibility that con $\mathrm{A}$ interaction with glycolipids in crude phospholipid preparations could account for the observed effects.

Preliminary experiments suggested that tissue factor apoprotein contains mannose ( $Y$. Nemerson, unpublished data). Accordingly, we chose to test for a possible effect of con $\mathrm{A}$ on tissue factor activity. Con A preferentially binds mannosyl or glucosyl residues in which the reducing terminus is linked to another substituent (e.g., $\alpha$-methyl mannoside or glucoside, sucrose, dextrans such as Sephadex, the mannosyl or glucosyl residues in glycoproteins, and, through their surface glycoproteins, various cell types) $(20,6,11,21-24)$. In neutral solutions, con $A$ is a tetramer with four binding sites (25-27). Thus, if a polysaccharide presents more than one binding site aggregation occurs, much the same as in an antibody-antigen complex. Binding to an oligosaccharide is freely reversible by addition of another saccharide for which con A has an affinity (6).

Con A inhibition of crude tissue factor is completely relieved by the addition of $\alpha$-methyl-D-glucoside. At high concentrations of con $A$, recovery of activity of purified tissue factor is incomplete (about $50 \%$ of the activity of the protected sample, which contained as much con A but included $\alpha$-methyl-D-glucoside from the beginning). Although jack bean meal does contain a variety of hydrolytic enzymes, we cannot attribute the loss to known functions of possible contaminants of the con A preparation. Since $\alpha$-methyl-D-glucoside prevents loss of activity in the presence of con $A$, it appears that degradation is not due to proteolysis. This preparation of con A does not hydrolyze $p$-nitrophenyl$\alpha$-mannoside or $p$-nitrophenyl- $\beta-N$-acetyl-glucosamine, and thus is free of two of the most likely glycosidase contaminants $(28,29)$. Since the crude tissue factor preparation contains $2,000-4,000$ times as much protein in the incubation, it is not unexpected that any losses would be magnified with the purified preparation. The point remains, however, that $\alpha$-methyl-D-glucoside addition to the inhibited sample does result in an increase in activity, suggesting that con $A$ itself is inhibiting tissue factor activity.

That the effect of con A is due to a reversible binding to tissue factor is borne out by experiments in which con A-Sepharose binds tissue factor activity. Upon specific elution with $\alpha$-methyl-D-glucoside, a 10 fold increase in specific activity is achieved."

There are several mechanisms by which con A could interfere with coagulant activity, but the experiments reported here cannot discriminate among the possibilities. Con $\mathrm{A}$ is a multivalent molecule and can therefore form large aggregates, thereby limiting diffusion of factor VII to internal sites, and resulting in an apparent loss of activity. Con A could also form intramolecular bridges over the active site and block access to factor VII. If the carbohydrate residue is close to the factor VII binding site, the bulk of the con A tetramer could be sufficient to interfere with an adequate fit of factor VII on the tissue factor lipoprotein surface. Finally, the binding of con A to the carbohydrate would alter the ionic environment in the immediate region of the carbohydrate, possibly inducing conformational changes unfavorable to factor VII binding.

We have previously demonstrated that tissue factor apoprotein stains positively for carbohydrate in acrylamide gels, suggesting a glycoprotein nature (1). Furthermore, the lipophilic nature of the molecule is consonant with membrane constituents, evidence which has been substantiated by antigenic localization $(2,3)$ and factor VII binding sites (4). The results reported here offer additional indirect evidence for the membrane localization of this activity. The carbohydrate portion of a glycoprotein probably serves to orient the molecule in relation to the aqueous phase surrounding the membrane. The fact that con A readily inhibits the biological activity suggests that the coagulant site of the molecule might be in close proximity to extracellular fluid phases, although normally protected in vivo.

\footnotetext{
'Pitlick, F. A. Manuscript in preparation.
} 


\section{ACKNOWLEDGMENTS}

The author thanks Lionel Clyne and Rita Sznycer-Laszuk for capable technical assistance. Dr. Jolyn Jesty generously provided the factor $\mathrm{X}$ for assays and Dr. Yale Nemerson suggested helpful manuscript revisions.

This work has been supported by grants from the American Heart Association (70-740) and the National Heart and Lung Institute, National Institutes of Health (HL09057 and HL-16126).

\section{REFERENCES}

1. Nemerson, Y., and F. A. Pitlick. 1970. Purification and characterization of the protein component of tissue factor. Biochemistry. 9 : 5100-5105.

2. Zeldis, S. M., Y. Nemerson, F. A. Pitlick, and T. L. Lentz. 1972. Tissue factor (thromboplastin): localization to plasma membranes by peroxidase-conjugated antibodies. Science (Wash. D. C.). 175: 766-768.

3. Stemerman, M., F. A. Pitlick, and J. Cintron. 1974. Tissue factor and the injured artery: detection of "endothelial cells" by distinct antigenicity during re-endothelialization. Fed. Proc. 33: 628. (Abstr.)

4. Goldenfarb, P. B., F. A. Pitlick, and Y. Nemerson. 1973. Factor VII : a biological probe for initiation sites of blood coagulation. J. Clin. Invest. 52: 34 a. (Abstr.)

5. Maynard, J. R., C. A. Heckman, F. A. Pitlick, and Y. Nemerson. 1974. Tissue factor activity of the cell surface coat. Fed. Proc. 33: 243. (Abstr.)

6. Goldstein, I. J., C. E. Hollerman, and E. E. Smith 1965. Protein-carbohydrate interaction. II. Inhibition studies on the interaction of concanavalin A with polysaccharides. Biochemistry. 4: 876-883.

7. Steinemann, A., and L. Stryer. 1973. Accessibility of the carbohydrate moiety of rhodopsin. Biochemistry. 12: 1499-1507.

8. Zacharski, L. R., R. Rosenstein, P. G. Phillips. 1974. Concanavalin-A inhibition of tissue factor (thromboplastin) activity. Blood J. Hematol. In press.

9. Lowry, O. H., N. J. Rosebrough, A. L. Farr, and R. J. Randall. 1951. Protein measurement with the Folin phenol reagent. J. Biol. Chem. 193 : 265-275.

10. Chen, P. S., Jr., T. Y. Toribara, and H. Warner. 1956. Microdetermination of phosphorus. Anol. Chem. 28: 1756-1758.

11. Agrawal, B. B. L., and I. J. Goldstein. 1967. Proteincarbohydrate interaction. VI. Isolation of concanavalin $A$ by specific adsorption on cross-linked dextran gels. Biochim. Biophys. Acta. 147 : 262-271.

12. Nemerson, Y. 1966. The reaction between bovine brain tissue factor and factors VII and X. Biochemistry. 5: 601-608.

13. Rickles, F. R., J. A. Hardin, F. A. Pitlick, L. W. Hoyer, and M. E. Conrad. 1973. Tissue factor activity in lymphocyte cultures from normal individuals and patients with hemophilia A. J. Clin. Invest. 52: 14271434.
14. Nemerson, Y. 1968. The phospholipid requirement of tissue factor in blood coagulation. J. Clin. Invest. 47: 72-80.

15. Nemerson, Y. 1969. Characteristics and lipid requirements of coagulant proteins extracted from lung and brain: the specificity of the protein component of tissue factor. J. Clin. Invest. 48: 322-331.

16. Nemerson, Y., and L. P. Clyne. 1974. An assay for coagulation factor VII using factor VII-depleted bovine plasma. J. Lab. Clin. Med. 83: 301-303.

17. Østerud, B., A. Berre, A-B. Otnaess, E. Bjфrklid, and H. Prydz. 1972. Activation of the coagulation factor VII by tissue thromboplastin and calcium. Biochemistry. 11 : 2853-2857.

18. Nemerson, Y., and M. P. Esnouf. 1973. Activation of a proteolytic system by a membrane lipoprotein: mechanism of action of tissue factor. Proc. Natl. Acad. Sci. U. S. A. 70: 310-314.

19. Jesty, J., and Y. Nemerson. 1974. Purification of factor VII from bovine plasma. Reaction with tissue factor and activation of factor X. J. Biol. Chem. 249: 509515.

20. Goldstein, I. J., C. E. Hollerman, and J. M. Merrick. 1965. Protein-carbohydrate interaction. I. The interaction of polysaccharides with concanavalin A. Biochim. Biophys. Acta. 97 : 68-76.

21. Sumner, J. B., S. F. Howell, and A. Zeissig. 1935. Concanavalin $\mathrm{A}$ and hemagglutination. Science (Wash. D. C.). $82: 65-66$.

22. Sumner, J. B., and S. F. Howell. 1936. The identification of the hemagglutinin of the jack bean with concanavalin A. J. Bacteriol. 32 : 227-237.

23. Burger, M. M. 1969. A difference in the architecture of the surface membrane of normal and virally transformed cells. Proc. Natl. Acad. Sci. U. S. A. 62: 994-1001.

24. Inbar, M., and L. Sachs. 1969. Interaction of the carbohydrate-binding protein concanavalin A with normal and transformed cells. Proc. Natl. Acad. Sci. U. S. A. 63: $1418-1425$.

25. Olson, M. O. J., and I. E. Leiner. 1967. The association and dissociation of concanavalin $\mathrm{A}$, the phytohemagglutinin of the jack bean. Biochemistry. 6: 3801-3808.

26. Kalb, A. J., and A. Lustig. 1968. The molecular weight of concanavalin A. Biochim. Biophys. Acta. 168: 366367.

27. Wang, J. L., B. A. Cunningham, and G. M. Edelman 1971. Unusual fragments in the subunit structure of concanavalin A. Proc. Natl. Acad. Sci. U. S. A. 68: $1130-1134$.

28. Li, Y-T. 1967. Studies on the glycosidases in Jack Bean Meal. I. Isolation and properties of $\alpha$-mannosidase. $J$. Biol. Chem. 242: 5474-5480.

29. Li, S-C, and Y-T Li. 1970. Studies on the glycosidases of jack bean meal. III. Crystallization and properties of $\beta$ - $N$-acetylhexosaminidase. J. Biol. Chem. 245: 51535160. 